\title{
Advances in Quaternary Studies: The Contribution of the Mammalian Fossil Record
}

\author{
Maria Rita Palombo \\ IGAG-CNR, c/o, Department of Earth Sciences, Sapienza University of Rome, 00185 Roma, Italy; \\ mariarita.palombo@uniroma1.it
}

Received: 7 November 2018; Accepted: 14 November 2018; Published: 23 November 2018

Explaining the multifaceted, dynamic interactions of the manifold factors that have modelled throughout the ages the evolutionary history of the biosphere is undoubtedly a fascinating and challenging task that has been intriguing palaeontologists, biologists and ecologists for decades, in a never-ending pursuit of the causal factors that controlled the evolutionary dynamics of the Earth's ecosystems throughout deep and Quaternary time.

The biological processes leading to today's biodiversity and biogeographical setting intertwine with and depend on constant palaeogeographical, climatic and environmental changes. Deciphering the complex network of mechanisms driving fauna evolution is likewise of crucial relevance to understanding the true meaning of the so-called sixth mass extinction, and to plan appropriate actions for biodiversity conservation in view of the ongoing climatic warming (e.g., [1-5]).

The Special Issue, "Advances in Quaternary Studies: The Contribution of the Mammalian Fossil Record" aims to present the research diversity within the field, highlighting the importance of analysing past processes to understanding the present, and foreseeing the future.

The Quaternary period is of particular interest to scholars working on fauna dynamics (particularly on terrestrial mammalian species), and ecosystem modifications throughout time, because it not only records the most dramatic change in the Earth's climate system, but also provides a quantity of detailed palaeontological and archaeological evidence for geologically short time slices. The rich amount of information, on the one hand permits us to discriminate even minor functional and taxonomical fauna turnovers at a local geographical scale and, on the other hand, may often have, at least with regard to the terrestrial domain, a merely local significance and/or be discontinuous in time and across space. This fact may hamper the proper appraisal of the ecosystem's evolution on a large, regional geographical scale. Moreover, the factors driving the remodelling of the range of a species, and the time and mode of its dispersal and diffusion into a given region, mostly vary from species to species and from one territory to another (e.g., [6-8]). As a result, correlations and biochronological assessments of local fauna assemblages (LFAs) may be difficult, especially if firm chronostratigraphical constraints are unavailable, and the identification of taxa is doubtful, confusing or controversial. This is why any new data, even if it apparently has limited relevance at the regional scale, may prove to be of particular interest when scrutinizing the causal factors leading to the progressive modification of mammalian communities during the Quaternary period.

Any correct evolutionary inference from the fossil record and any hypothesis about the environmental effects on fauna dynamics require a compelling chronological framework and will underpin a firm taxonomical identification of taxa. As highlighted by Navarro et al. [9] (p. 1), "such a postulate depends on the sensitivity of classification criteria and their actual variations within and between species". Navarro et al. [9] tried to find some "objective criteria" to correctly identify two vole species (Microtus arvalis and Microtus agrestis, quite common in Western European Pleistocene sites), by developing a new method for describing the overall shape of the first lower molar. The model, 
ensuring the proper identification of the two species, may provide some clues to better understanding their chronology, dispersal and dispersion during the Quaternary.

The revision of well-known classic LFAs can sometimes shed new light on the biochronological range and fauna turnover of species either at the local and regional scales. This is the case, for instance, of the Greek Sésklo mammalian fauna, previously regarded as Early Pleistocene (Gelasian, middle Villafranchian, lower MN 17 "zone") in age. Analysis of new material and the revision of the evidence in historical collections ascertained that it actually consists of two different LFAs [10], ranging in age from the Late Pliocene to the Early Pleistocene. The Late Pliocene (early Villafranchian, MN16a) LFA is characterised by the presence of Plesiohipparion cf. P. shanxiense, replaced by a large Equus in the Early Pleistocene LFA. Accordingly, hipparionine and the stenonoid horses did not co-occur together at Sésklo, as was conversely the case in some middle Villafranchian South European sites such as Montopoli (Italy) (MN16b) and Villaroya (Spain) (MN 17, 2.128-2.14 Ma [11]), where Hipparion sp. [12], and Plesiohipparion ([13,14] and references therein) were recorded, respectively. As stated by Athanassiou [10], the composition and structure of the low-level Sésklo LFA suggest a palaeoenvironment apparently more open and less wooded and humid than those prevailing roughly contemporaneously in some SW European territories (e.g., France and Italy) $[15,16]$. This assumption is rather consistent with the spread during the Pliocene of Artemisia grasslands, first in the Eastern Mediterranean and later in the Western Mediterranean areas, alongside a decrease in the most thermophilus plants with a high water requirement, and an increase in herbs and mesothermic and seasonally-adapted plants (cf. [17]). It is worth noting, however, that the analysis of the, rich and diversified Greek fauna of the Late Pliocene from Milia (Grevena, Western Macedonia) (early Villafranchian, MN 16a, perhaps $>3.14 \mathrm{Ma}$ ), depicts a somewhat different scenario. The mammal remains collected in the various localities around the Milia village would have had "a short temporal distribution" and "the presence of Agriotherium would constrain the age of the Milia assemblage to the MN16a" [18] (p. 13). Some chronological differences from one locality to another cannot be dismissed, considering, for instance, the discrepancy in ecological clues provided by the MIL 2 and MIL 4 LFAs, which would suggest, according to Vlachos et al. [18] (p. 14) the presence of "a potential barrier between these two localities".

Whether the Pliocene Sésklo and Milia LFAs might actually represent two different climatic and chronological phases, and might be related respectively to the Late Pliocene cooling (recorded around 2.9-2.8 Ma ago) (e.g., [15,19,20]) and the mid-Piacenzian warm period (3.264-3.025 Ma) (e.g., [21,22]) or not, it is still an open question, requiring further investigation.

The spread of open environments was, instead, particularly evident (despite some differences at the local scale) during the Early Middle Pleistocene Transition (EMPT [23]) (cf. [24] and references therein), as it is at least partially supported by the functional morphology of Carnivora taxa recorded in the late Early Pleistocene Apollonia 1 Greek LFA (about 1.3-1.0 Ma), as well as by the comparison of their guild structure to that of modern carnivoran communities from known environments [25]. Data provided by the analysis of Apollonia 1 Carnivora, combined with evidence from the overall composition of the LFA and ecological traits of some herbivorous taxa, on the one hand, confirm the renewal of the late Early Pleistocene fauna from shortly before the Jaramillo time, and on the other hand depict a patchy/mosaic landscape (an open environment with a grassy floor and a few wooded areas) [25]. Scrutinizing mammal fauna dynamics and functional diversity at a very local scale may be a useful support to infer the complexity of the regional scenario. In fact, a comparison of the changes shown by the large South European mammal palaeocommunities has already shown a marked increase in the regionalization of the faunal record during the EMPT, while only modest differences characterised the vegetation dynamics (cf. $[24,26]$ and references in those papers), highlighting the very complex relationships among the climate, vegetation, mammals and territorial physiography.

Overall, the evolutionary patterns of climate-related, long-term faunal changes appear to be the cumulative result of both the responses of individual species to physical and biotic environmental changes, and the different interplay of niche differentiation and biotic interactions in 
each territory, which in turn shaped the fauna composition and species diversity at a regional (e.g., sub-continental) scale.

A reappraisal of evidence and new investigations of the MIS 5e (Eemian/Mikulinian/Ipswichian interglacial) small mammal LFAs at the European scale made by Markova and Puzachencko [27] (p. 12) underlined, for instance, "a considerable number of geographical variants, each with its own specificity in species composition and species richness", and the dominance of species. As pointed up by the authors [27], evidence provided by the Last Interglacial small mammal fossil record may imply the presence of widespread forests in the western and most of the central and eastern European territories, while in the southern and easternmost territories, prolonged drought conditions might have accounted for the presence of open xerophytic steppes and mesophytic forest steppes.

Some useful clues for a better understanding of mammal biochronology, palaeoecology and palaeoenvironmental evolution during the Last Glacial (LG) (MIS 2) come from the study of small and large French mammals, which highlights the possible role of Cricetus cricetus as a sort of local (SW France) "chronological marker" of the Younger Dryas (Greenland Stadial GS1, 12.9-11.7 cal. ka BP) [28], and the significance of the mammalian fossil record for disentangling taxa dispersal dynamics at a very local geographical scale [29]. The faunal assemblages from the Coulet des Roches stratigraphical sequences (Southern France) provide some pieces of information on palaeoclimatic changes and their effects on large and small mammal dispersal during a fairly short geological time slice, ranging from the late Denekamp Interstadial 38.2-28.6 cal. ka BP) (Greenland Interstadial GI 4 (if not from the Hengelo Interstadial, GI 10, 43.3-40.8 cal. ka BP) to the Subboreal Holocene phase (5.5-2.1 cal. ka BP). Some of the analysed taxa, for instance, show some phenotypic plasticity (sometimes expected, as in the case of horse autopodium), possibly relying on ecological adaptation in response to the varying climatic and environmental conditions. According to Crégut-Bonnoure et al. [29], the results of the palaeoecological study may suggest that the lowland areas, i.e., the plains along the Rhône River, acted as a corridor for temperate species displacing to Provence during cold periods, and from this territory to Western Europe during temperate periods. In contrast, the highland areas acted as a geographical barrier and "cryptic Southern refugia" for "cold species" during interglacial phases.

Although the actual nature and significance of the displacement of "cold" and "warm temperate" species (e.g., Clementsian [30] versus Gleasonian model [31]), and the "refugia" concept are still vaguely understood and defined (e.g., among several others, [32-35] and references in those papers), a number of pieces of evidence underline the key role that climate-driven dispersal bioevents had both in shaping fauna dynamics and evolution, and in conditioning the biodiversity and biogeography of land mammalian fauna at any point in time in any region. A mammal population enlarging its geographical range into new territories, or simply moving from one habitat patch to another, may merge alien species, or augment their abundance if already present, in the mammalian communities previously inhabiting the territory, changing their ecological structure. This event then gives rise to new internal dynamics that, in turn, may lead to a progressive reconstruction of the mammalian fauna, changes in the dominance and the possible demise of some species.

Dispersal, hence, is one among the fundamental processes in biogeography and a factor to carefully consider when drawing correlations between distant stratigraphical sequences and analysing climate-driven faunal turnover (e.g., among several others [6,7,36-39] and references in those papers).

Quaternary climate forcing, in particular precessions that had an important control on seasonality, induced some gradual alterations and latitudinal displacements in terrestrial biomes, particularly with regard to the boreal mid-latitude biomes, triggering the modification of the geographical range of a number of mammal taxa. The effect of climatic oscillations, combined with the presence of geographical and ecological barriers and their change throughout time, conceivably exerted a strong influence on the dispersal and dispersion of mammalian species across and between continents. According to Croitor [40], for instance, the results obtained by the analysis and identification of two new Rucervus species at Valea Graunceanului (Romania) (an LFA whose taxonomic composition indicates a middle Villafranchian (MN 17) age, younger than, and not chronologically correlated 
with (cf. [40] (p. 2)), the Italian "Olivola Faunal Unit" (see, e.g., [41,42] references therein) may shed some light on the faunal exchanges among Southeastern Europe, the Near East and Southern Asia during the Early Pleistocene (Gelasian). The author in [40], analysing the evolutionary radiation and dispersals of Rucervus in the palaeobiogeographical context of faunal exchanges between southeastern Europe, the Caucasus, and Southern Asia, suggested they might have been controlled "by the complex interaction of geographic obstacles, such as Bosporus and Manych Straight, the climate barrier from the north of the Greater Caucasus range, and the $41 \mathrm{kyr}$ glacial cycles that repeatedly closed the Bosporus and thus triggered the two-way faunal exchange between SE Europe and the Near East, and, apparently, the further westwards dispersal of the archaic hominins in Eurasia" (cf. [40] (p. 28)).

The mode, time and the factors promoting dispersals and dispersal trajectories along geographical gradients, and the settlement of archaic and modern human species from Africa towards Eurasia, the way they interacted with fauna, their exploitation of resources and procurement strategies and the evolution of and changes in such behaviour in the course of Palaeolithic are still open questions. The matter has received increasing attention, particularly during the last couple of decades (e.g., among several others, [43-51] and references in those papers), also from the perspective of the modern human-animal-environment interaction (e.g., [52]). In particular, the role that prehistoric man might have had in megafauna extinction (e.g., among several others for different opinions [43-60], and references in those papers), and the question of "hunting versus scavenging" behaviour in the Lower Palaeolithic are among the most intriguing and debated topics in the literature.

Large mammals, especially medium-to-large-sized mammals, were undoubtedly a relevant resource for prehistoric humans since the Lower Palaeolithic, despite their different abilities and procurement behaviour. The capacity of humans to obtain meat, particularly as regards Early Palaeolithic hominins, was likely influenced by the number and variety of the prey, the structure of the fauna (i.e., the ecological characteristics of the prey and predators), and the degree of human-predator competition to access this trophic resource (e.g., [61] and references therein).

A fresh viewpoint on the hunting behaviour of human groups during the Pleistocene is provided by Agam and Barkai [62]. The authors, in order to decipher the extent and practices of very large game hunting (i.e., elephants and mammoths), critically revised a large amount of archaeological, ethnographical and ethno-historical data. Overall, the available evidence supports the hypothesis that early humans had enough skills to actively and regularly hunt elephants and mammoths, although the impact of hunting on proboscidean populations was possibly moderate, and hunting activity was not the major factor in their Late Pleistocene extinction. Agam and Barkaiin [62] (p. 20) suggest "that a group of hunter-gatherers could have sustain to a relatively substantial period of time following the hunt of a single mega herbivore, and thus such hunt was not carried out rather frequently... the effort, risk and time invested in such a complex activity were clearly considerable", but "the nutritional, economic and social benefits of such hunting were greater still, making all the effort and exertion involved fully worth it".

The Late Pleistocene/Early Holocene megafauna extinction likely resulted from the multifaceted interaction of several biotic and abiotic factors, which interacted differently and affected each species, depending on its status and intrinsic characteristics. As a result, it is a challenging task to depict a general model able to explain the causal factors, and the time and mode of this globally-documented, selective extinction phenomenon. With regard to Europe, for instance, it seems rational to suppose that climate and environmental changes had a major influence on the less ecologically flexible species, while the direct or indirect impact of humans (hunting, competition, habitat fragmentation) likely increased the risk, or accelerated the process, of extinction for species already stressed by environmental changes, range contraction and a reduction of occupancy and population size.

The more data that we acquire, the more methodological approaches that we develop, the more our knowledge on the Quaternary world will enhance, likely enabling us to answer some of these open and debated questions, and to better learn from the past in order to prepare for the future. 
Each and every new piece of information, even if limited, may represent an important piece to complete the puzzle, whether it is a taxonomical, biochronological, ecological or palaeogeographical datum. The papers by Mauch Lenardić et al. [63], Valli [64], and Mol et al. [65] supply, for instance, some useful pieces of such information. Although the first paper describes very few Late Pleistocene-Holocene large mammal remains, it provides some details that in the future may be useful to better clarify the palaeoenvironment evolution of the poorly known Podravina Croatian region [63].

In the second paper [64], the detailed analysis of the cervid fossil remains from the late Pleistocene fossiliferous deposit of Lagoa dos Porcos ("Serra da Capivara", Piauí, Brazil) led to the identification of the large deer Morenelaphus sp., de facto extending the palaeogeographical range of the genus thus far unknown in the region. In addition, the palaeoecological analysis provides some suggestions for a discussion of the palaeoecological significance of the data provided by deer remains found in the karstic area of this territory [64].

The third paper [65] confirms the utility of any small piece of information even if related to well-known taxa, showing that the identification of the rarely found deciduous and newly-developing permanent mammoth tusks may enable us not only to document the species' presence, but also to obtain some information about ontogenetic development, and perhaps population structure.

The variety of data presented in this volume confirms once more the importance of the mammalian fossil record for Quaternary study. The contribution of an extensive analysis of the large and small mammals of the Quaternary (e.g., chronology, palaeobiology, palaeoecology, palaleohistology, taxonomy, and taphonomy), performed by means of new, advanced, maybe alternative methods that may be further developed in the future, and integrated with evidence from other disciplines (e.g., archaeology, geochemistry, geology s.l. sedimentology, stratigraphy, palaeobotany, palaeogeography, zoology, etc.), is crucial in order to stretch our imagination beyond the present, and collects insights to develop future scenarios for the Earth's ecosystems by drawing on lessons from the past.

Funding: This research received no external funding.

Conflicts of Interest: The author declares no conflicts of interest.

\section{References}

1. Barnosky, A.D. Transforming the global energy system is required to avoid the sixth mass extinction. MRS Energy Sustain. 2015, 2, 1-13. [CrossRef]

2. McCallum, M.L. Vertebrate biodiversity losses point to a sixth mass extinction. Biodivers. Conserv. 2015, 24, 2497-2519. [CrossRef]

3. Ceballos, G.; Ehrlich, P.R. The misunderstood sixth mass extinction. Science 2018, 360, 1080-1081. [PubMed]

4. Keller, G.; Mateo, P.; Punekar, J.; Khozyem, H.; Gertsch, B.; Spangenberg, J.; Bitchong, A.M.; Adatte, T. Environmental changes during the Cretaceous-Paleogene mass extinction and Paleocene-Eocene Thermal Maximum: Implications for the Anthropocene. Gondwana Res. 2018, 56, 69-89. [CrossRef]

5. Sigwart, J.D.; Bennett, K.D.; Edie, S.M.; Mander, L.; Okamura, B.; Padian, K.; Wheeler, Q.; Winston, J.; Yeung, N. Measuring Biodiversity and Extinction-Present and Past. Integr. Comp. Biol. 2018, icy113. [CrossRef]

6. Colbert, J.; Baguette, M.; Benton, T.G.; Bullock, J.M. (Eds.) Dispersal Ecology and Evolution; Oxford University Press: Oxford, UK, 2012; 462p.

7. Palombo, M.R. Discrete dispersal bioevents of large mammals in Southern Europe in the post-Olduvai Early Pleistocene: A critical overview. Quat. Int. 2017, 431, 3-19. [CrossRef]

8. Williams, J.E.; Blois, J.L. Range shifts in response to past and future climate change: Can climate velocities and species' dispersal capabilities explain variation in mammalian range shifts? J. Biogeogr. 2018, 45, 2175-2189. [CrossRef]

9. Navarro, N.; Montuire, S.; Laffont, R.; Steimetz, E.; Onofrei, C.; Royer, A. Identifying Past Remains of Morphologically Similar Vole Species Using Molar Shapes. Quaternary 2018, 1, 20. [CrossRef] 
10. Athanassiou, A. A Villafranchian Hipparion-Bearing Mammal Fauna from Sésklo (E. Thessaly, Greece): Implications for the Question of Hipparion-Equus Sympatry in Europe. Quaternary 2018, 1, 12. [CrossRef]

11. Pueyo, E.L.; Muñoz, A.; Laplana, C.; Parés, J.M. The Last Appearance Datum of Hipparion in Western Europe: Magnetostratigraphy along the Pliocene-Pleistocene boundary in the Villarroya Basin (northern Spain). Int. J. Earth Sci. 2016, 105, 2203-2220. [CrossRef]

12. Rook, L.; Cirilli, O.; Bernor, R.L. A Late Occurring "Hipparion" from the middle Villafranchian of Montopoli, Italy (early Pleistocene; MN16b; ca. 2.5 Ma). Boll. Soc. Paleontol. Ital. 2017, 56, 333-339.

13. Bernor, R.L.; Sun, B. Morphology through ontogeny of Chinese Proboscidipparion and Plesiohipparion and observations on their Eurasian and African relatives. Vertebr. Palasiat. 2015, 5, 73-92.

14. Bernor, R.L.; Meshida, K.; Sun, B. Phylogenetic signature in the juvenile skulls and cheek teeth of Pleistocene Proboscidipparion sinense, China. Riv. Ital. Paleontol. Stratigr. 2015, 121, 255-264.

15. Bertini, A.; Ciaranfi, N.; Marino, M.; Palombo, M.R. Proposal for Pliocene and Pleistocene land-sea correlation in the Italian area. Quat. Int. 2010, 219, 95-108. [CrossRef]

16. Combourieu-Nebout, N.; Bertini, A.; Russo-Ermolli, E.; Peyron, O.; Klotz, S.; Montade, V.; Fauquette, S.; Allen, J.; Fusco, F.; Goring, S.; et al. Climate changes in the central Mediterranean and Italian vegetation dynamics since the Pliocene. Rev. Palaeobot. Palynol. 2015, 218, 127-147. [CrossRef]

17. Jiménez-Moreno, G.; Popescu, S.M.; Ivanov, D.; Suc, J.P. Neogene flora, vegetation and climate dynamics in southeastern Europe and the northeastern Mediterranean. In Deep-Time Perspectives on Climate Change: Marrying the Signal from Computer Models and Biological Proxies; Williams, M., Haywood, A.M., Gregory, F.J., Schmidt, D.N., Eds.; The Micropalaeontological Society, Special Publications, The Geological Society: London, UK, 2007; pp. 503-516.

18. Vlachos, E.; Tsoukala, E.; Crégut-Bonnoure, E.; Guérin, C.; Mol, D. The Paradise Lost of Milia (Grevena, Greece; Late Pliocene, Early Villafranchian, MN15/MN16a): Faunal Composition and Diversity. Quaternary 2018, 1, 13. [CrossRef]

19. Backman, J.; Jakobsson, M.; Frank, M.; Sangiorgi, F.; Brinkhuis, H.; Stickley, C.; O’Regan, M.; Løvlie, R.; Pälike, H.; Spofforth, D.; et al. Age model and core-seismic integration for the Cenozoic Arctic Coring Expedition sediments from the Lomonosov Ridge. Paleoceanography 2018, 23, PA1S03. [CrossRef]

20. Whitehead, J.M.; Wotherspoon, S.; Bohaty, S.M. Minimal Antarctic sea ice during the Pliocene. Geology 2005, 33, 137-140. [CrossRef]

21. Haywood, A.M.; Dowsett, H.J.; Dolan, A.M. Integrating geological archives and climate models for the mid-Pliocene warm period. Nat. Commun. 2018, 7, 10646. [CrossRef] [PubMed]

22. Prescott, C.L.; Dolan, A.M.; Haywood, A.M.; Hunter, S.J.; Tindall, J.C. Regional climate and vegetation response to orbital forcing within the mid-Pliocene Warm Period: A study using HadCM3. Glob. Planet. Chang. 2018, 161, 231-243. [CrossRef]

23. Maslin, M.A.; Brierley, C.M. The role of orbital forcing in the Early Middle Pleistocene Transition. Quat. Int. 2015, 389, 47-55. [CrossRef]

24. Palombo, M.R. Faunal dynamics in SW Europe during the late Early Pleistocene: Palaeobiogeographical insights and biochronological issues. C. R. Palevol. 2018, 17, 247-261. [CrossRef]

25. Koufos, G.D. New Material and Revision of the Carnivora, Mammalia from the Lower Pleistocene Locality Apollonia 1, Greece. Quaternary 2018, 1, 6. [CrossRef]

26. Magri, D.; Palombo, M.R. Early to Middle Pleistocene dynamics of plant and mammal communities in South West Europe. Quat. Int. 2013, 288, 63-72. [CrossRef]

27. Markova, A.; Puzachenko, A. Preliminary Analysis of European Small Mammal Faunas of the Eemian Interglacial: Species Composition and Species Diversity at a Regional Scale. Quaternary 2018, 1, 9. [CrossRef]

28. Royer, A.; Sécher, A.; Langlais, M. A Brief Note on the Presence of the Common Hamster during the Late Glacial Period in southwestern France. Quaternary 2018, 1, 8. [CrossRef]

29. Crégut-Bonnoure, E.; Boulbes, N.; Desclaux, E.; Marciszak, A. New Insights into the LGM and LG in Southern France (Vaucluse): The Mustelids, Micromammals and Horses from Coulet des Roches. Quaternary 2018, 1, 19. [CrossRef]

30. Clements, F.E. Plant Succession: An Analysis of the Development of Vegetation; Carnegie Institution of Washington, Cornell University Library: Washington, DC, USA, 1926; pp. 1-658.

31. Gleason, H.A. The individualistic concept of the plant association. Bull. Torrey Bot. Club 1926, 53, 7-26. [CrossRef] 
32. Bhagwat, S.A.; Willis, K.J. Species persistence in northerly glacial refugia of Europe: A matter of chance or biogeographical traits? J. Biogeogr. 2008, 35, 464-482. [CrossRef]

33. Godbold, A.; Schoepfer, S.; Shen, S.; Henderson, C.M. Precarious ephemeral refugia during the earliest Triassic. Geology 2017, 45, 607-610. [CrossRef]

34. Morales-Barbero, J.; Martinez, P.A.; Ferrer-Castán, D.; Olalla-Tárraga, M.Á. Quaternary refugia are associated with higher speciation rates in mammalian faunas of the Western Palaearctic. Ecography 2028, 41, 607-621. [CrossRef]

35. Stewart, J.R.; Lister, A.M.; Barnes, I.; Dalén, L. Refugia revisited: Individualistic responses of species in space and time. Proc. R. Soc. Lond. B: Biol. Sci. 2010, 277, 661-671. [CrossRef] [PubMed]

36. Blois, J.L.; Hadly, E.A. Mammalian response to Cenozoic climate change. Annu. Rev. Earth Planet. Sci. 2009, 37, 181-208. [CrossRef]

37. Palombo, M.R. Deconstructing mammal dispersals and faunal dynamics in SW Europe during the Quaternary. Quat. Sci. Rev. 2014, 96, 50-71. [CrossRef]

38. Vrba, E.S. Mass turnover and heterochrony events in response to physical change. Paleobiology 2005, 31, 157-174. [CrossRef]

39. Woodburne, M.O.; Gunnell, G.F.; Stucky, R.K. Climate directly influences Eocene mammal faunal dynamics in North America. Proc. Natl. Acad. Sci. USA 2009, 106, 13399-13403. [CrossRef] [PubMed]

40. Croitor, R. A Description of Two New Species of the Genus Rucervus (Cervidae, Mammalia) from the Early Pleistocene of Southeast Europe, with Comments on Hominin and South Asian Ruminants Dispersals. Quaternary 2018, 1, 17. [CrossRef]

41. Palombo, M.R. Biochronology of terrestrial mammals and Quaternary subdivisions: A case study of large mammals from the Italian peninsula. Il Quat. Ital. J. Quat. Sci. 2009, 22, 291-306.

42. Rook, L.; Martínez-Navarro, B. Villafranchian: The long story of a Plio-Pleistocene European large mammal biochronologic unit. Quat. Int. 2010, 219, 134-144. [CrossRef]

43. Agustì, J.; Lordkipanidze, D. Out of Africa: An alternative scenario for the first human dispersal in Eurasia. Mètode Sci. Stud. J.: Ann. Rev. 2018, 8, 98-105. [CrossRef]

44. Boivin, N.; Petraglia, M. (Eds.) Human Dispersal and Species Movement; Cambridge University Press: Cambridge, UK, 2017; 529p.

45. Dominguez-Rodrigo, M.; Pickering, T.R. The meat of the matter: An evolutionary perspective on human carnivory. Azania Archaeol. Res. Afr. 2017, 52, 4-32. [CrossRef]

46. Lamb, H.F.; Bates, C.R.; Bryant, C.L.; Davies, S.J.; Huws, D.G.; Marshall, M.H.; Roberts, H.M. 150,000-year palaeoclimate record from northern Ethiopia supports early, multiple dispersals of modern humans from Africa. Sci. Rep. 2018, 8, 1077. [CrossRef] [PubMed]

47. O'Connell, J.F.; Allen, J.; Williams, M.A.; Williams, A.N.; Turney, C.S.; Spooner, N.A.; Kamminga, J.; Brown, G.; Cooper, A. When did Homo sapiens first reach Southeast Asia and Sahul? Proc. Natl. Acad. Sci. USA 2018, 115, 8482-8490. [CrossRef] [PubMed]

48. Parkinson, J.A. Revisiting the hunting-versus-scavenging debate at FLK Zinj: A GIS spatial analysis of bone surface modifications produced by hominins and carnivores in the FLK 22 assemblage, Olduvai Gorge, Tanzania. Palaeogeogr. Palaeoclimatol. Palaeoecol. 2018, 511, 29-51. [CrossRef]

49. Rodríguez, J.; Mateos, A. Carrying capacity, carnivoran richness and hominin survival in Europe. J. Hum. Evol. 2018, 118, 72-88. [CrossRef] [PubMed]

50. Szymanek, M.; Julien, M.A. Early and Middle Pleistocene climate-environment conditions in Central Europe and the hominin settlement record. Quat. Sci. Rev. 2018, 198, 56-75. [CrossRef]

51. Templeton, A.R. Chapter 5 -World Dispersals and Genetic Diversity of Mankind: The Out-of-Africa Theory and Its Challenges. Hum. Nat. 2017, 65-83. [CrossRef]

52. Nagaoka, L.; Rick, T.; Wolverton, S. The overkill model and its impact on environmental research. Ecol. Evol. 2018, 8, 9683-9696. [CrossRef] [PubMed]

53. Braje, T.J.; Erlandson, J.M. Human acceleration of animal and plant extinctions: A Late Pleistocene, Holocene, and Anthropocene continuum. Anthropocene 2013, 4, 14-23. [CrossRef]

54. Grayson, D.K.; Meltzer, D.J. A requiem for North American overkill. J. Archaeol. Sci. 2003, 30, 585-593. [CrossRef]

55. Lima-Ribeiro, M.S.; Diniz-Filho, J.A.F. Climate change, human overkill, and the extinction of megafauna: A macroecological approach based on pattern-oriented modelling. Evol. Ecol. Res. 2017, 18, 97-121. 
56. MacPhee, R.D.; Greenwood, A.D. Infectious disease, endangerment, and extinction. Int. J. Evol. Biol. 2013, 571939. [CrossRef] [PubMed]

57. Raczka, M.F.; Bush, M.B.; De Oliveira, P.E. The collapse of megafaunal populations in southeastern Brazil. Quat. Res. 2018, 89, 103-118. [CrossRef]

58. ̌ičánková, V.P.; Horsák, M.; Hais, M.; Robovský, J.; Chytrý, M. Environmental correlates of the Late Quaternary regional extinctions of large and small Palaearctic mammals. Ecography 2018, 41, 516-527. [CrossRef]

59. Sandom, C.; Faurby, S.; Sandel, B.; Svenning, J.C. Global late Quaternary megafauna extinctions linked to humans, not climate change. Proc. R. Soc. B 2014, 281, 20133254. [CrossRef] [PubMed]

60. Westaway, M.C.; Olley, J.; Grün, R. At least 17,000 years of coexistence: Modern humans and megafauna at the Willandra Lakes, South-Eastern Australia. Quat. Sci. Rev. 2017, 157, 206-211. [CrossRef]

61. Rodriguez-Gomez, G.; Rodríguez, J.; Martín-González, J.A.; Mateos, A. Evaluating the impact of Homo-carnivore competition in European human settlements during the early to middle Pleistocene. Quat. Res. 2017, 88, 129-151. [CrossRef]

62. Agam, A.; Barkai, R. Elephant and Mammoth Hunting during the Paleolithic: A Review of the Relevant Archaeological, Ethnographic and Ethno-Historical Records. Quaternary 2018, 1, 3. [CrossRef]

63. Mauch Lenardić, J.; Radović, S.; Oros Sršen, A.; Horvatinčić, N.; Kostešić, P.; Bermanec, V. Mammoths, Deer, and a Dog: Fossil and (Sub) Recent Allochthonous Remains from the Northeastern Croatia (Podravina Region), with the First Radiocarbon Dating of the Croatian Woolly Mammoths (Mammuthus primigenius). Quaternary 2018, 1, 11. [CrossRef]

64. Valli, A.M. Late Pleistocene Deer in the Region of the National Park "Serra da Capivara" (Piauí, Brazil). Quaternary 2018, 1, 4. [CrossRef]

65. Mol, D.; Bijkerk, A.; Ballard, J.P. Deciduous Tusks and Small Permanent Tusks of the Woolly Mammoth, Mammuthus primigenius (Blumenbach, 1799) Found on Beaches in The Netherlands. Quaternary 2018, 1, 7. [CrossRef]

(C) 2018 by the author. Licensee MDPI, Basel, Switzerland. This article is an open access article distributed under the terms and conditions of the Creative Commons Attribution (CC BY) license (http:/ / creativecommons.org/licenses/by/4.0/). 